\title{
OPTIMIZATION OF RECIPE TURKEY MEAT PATE
}

\author{
Tetiana Prylipko $^{1 凶}$, Tetiana Koval ${ }^{2}$, Volodymyr Kostash ${ }^{2}$, Tetiana Tocarchuk ${ }^{3}$, \\ Anatolii Tsvihun ${ }^{1}$
}

\begin{abstract}
${ }^{I}$ Department of Technology of Production, Processing and Standardization of Livestock Products State Agrarian and Engineering University in Podillyabld. 1 of the PDATU, 13 Shevchenko Str., Kamianets-Podilskyi, Khmelnytskyi Region, 32301, Ukraine

${ }^{2}$ Department of Agricultural Chemistry, Chemical and General Biological Sciences State Agrarian and Engineering University in Podillya bld. 1 of the PDATU, 13 Shevchenko Str., Kamianets-Podilskyi, Khmelnytskyi Region, 32301, Ukraine

${ }^{3}$ Department of Animal Hygiene and Veterinary Support of the Kennel Service of the National Police of Ukraine State Agrarian and Engineering University in Podillyabld. 1 of the PDATU, 13 Shevchenko Str., KamianetsPodilskyi, Khmelnytskyi Region, 32301, Ukraine ®prylipko.saeu@bk.ru

https://doi.org/10.34302/crpjfst/2020.12.4.11

Article history:

Received:

5 January 2020

Accepted: 15 October 2020

Keywords:

Turkey meat;

Meat pate;

Modes of preservation;

Safety indicators;

Prescription composition.

\section{ABSTRACT}

The article presents a study on optimization of the prescription of a paste made of Turkey meat. The technological scheme of production of pate, which determines the optimal operating parameters of industrial production of meat products, is presented. Five models of recipes for canned pates with a dietary orientation have been developed using mathematical modeling methods. Based on the results of the study of the biochemical composition and nutritional value, the optimal version of the recipe was selected, containing $31 \%$ of Turkey meat by weight. In addition to Turkey meat, the optimized recipe contains beef liver, fermented pork and chickpea flour. Qualitative characteristics of mechanical deboning of Turkey meat were studied. It is shown that Turkey meat meets the quality and safety requirements. The content of toxic elements in the studied batches did not exceed the acceptable values. The caloric content of Turkey meat pate is $226.8 \mathrm{kcal}$.
\end{abstract}

\section{Introduction}

The actual task of the meat and meat canning industry is to increase output and improve product quality by optimizing technological processes, identifying and using hidden reserves, and saving raw materials and energy resources. The range of products in the meat industry does not contain scientifically based recipes for canned meat products in the form of pates that meet the physiological standards of healthy nutrition.

Existing pate recipes are increasingly based on the possibility of using non-traditional raw materials and raw materials that can provide high quality. Turkey meat can be classified as dietary, and products made from it can be classified as delicatessen (Menon \& Rumer, 2015).

The modern meat market is full of broiler meat. It is necessary to expand the range of meat products from poultry meat by increasing other types of poultry-ducks, geese, and especially turkeys (Bouvard et al., 2015; Prylipko \& Kucius, 2014). Analysis of global trends in poultry farming shows a steady pattern of increasing Turkey production and consumption (Levy, Thaiss, \& Elinav, 2016; Verkhovna Rada of Ukraine, 1997).

The development of science-based regimes that ensure guaranteed output of high-quality 
products is impossible without an analytical description of the process, that is, a mathematical model of quality changes depending on changes in temperature and duration of heating of the product, the environment, the required and actual sterilizing effect. Recently, aseptic conservation is in high demand. This method is based on a new principle of thermal sterilization of food products (Alahakoon, Jayasena, Ramachandra, $\&$ Jo, 2015). The aseptic method of canning is one of the promising methods, but it has not yet been widely used in the practice of canning. When making canned food from products that have a uniform structure, you can use heat treatment of the product in the stream as it moves along the product pipeline (Menon \& Rumer, 2015). The development of rational modes of sterilization of pates should be reduced not only to the study of the possibility of reducing the sterilizing effect when obtaining industrial sterile products, but also to establish the dependencies of objective criteria for quality indicators and nutritional value.

The task in different countriesis increasing the efficiency of using protein and fat meat resources available in this state for food purposes should be solved. The solution is possible by developing a new generation of recipes and creating original technologies for meat products with a guaranteed content of macronutrients and micronutrients. The relevance of this study is that meat pates are in great demand among customers, depending on the region of their production, are a product that has a fairly long shelf life, they are convenient to use, so they can be used in travel, for cooking various dishes. Undoubtedly, the task of quality control and safety of new pates produced, including Turkey meat, is important (De Mey et al., 2014; Decker \& Park, 2010; JiménezColmenero, Sánchez-Muniz, \& OlmedillaAlonso, 2010).

Based on the above, the goal of experimental research was formulated: to confirm the theoretical background of the process of sterilization of meat pate from Turkey meat, to optimize its composition and determine the optimal mode parameters of sterilization to preserve the quality characteristics of the original products, to evaluate the safety indicators of Turkey meat and finished pate.

The formulation and justification of composition was based on the following postulates: formulation of requirements for ingredients and product that meets the task at hand; the selection of ingredients to provide desired properties to the product; establishing acceptable levels (lowest and highest fractions) of the ingredient in the recipe; determining the optimal levels of ingredients in the recipe.

\section{Materials and Methods}

The research tasks included: studying the safety indicators of Turkey meat mechanical deboning used for the production of canned pates, conducting computer modeling of recipes with a new type of raw materials and the balance of main components to meet the requirements of a healthy diet, establishing the dependence of changes in the quality of pate on the level of thermal loads and justification of rational modes of sterilization of pates, selecting a new generation of canned pates technology and evaluating the prospects for implementing developments in the industry.

The object of the study was the meat of Turkey mechanically deboned. Experimental studies were conducted using generally accepted and standard methods used to study the physical, chemical and bacteriological parameters of meat products (Ibatullin et al., 2014).

The task of calculating the optimal recipe was formulated as follows: with the known lists of ingredients acceptable for the production of a particular product, and the characteristics of each of them (moisture content, fat, protein, amino acids, fatty acids, trace elements, cost, etc.), as well as the required mass of the resulting product, it is necessary to determine in what quantities it is advisable to include the ingredients in the recipe in order to meet the established requirements for chemical composition, the quality of the finished product and the amount of use of individual ingredients or their combinations, to ensure the minimum (maximum) value of the optimization criterion 
(Ibatullin et al., 2017; Kabata-Pendias \& Szteke, 2015).

The following steps were performed sequentially: data collection, systematization and analysis by characteristics of the selected list of ingredients and product requirements; calculation of optimal recipe options with the selected optimization criterion and set restrictions; verification of the obtained option for the possibility of improving the optimization criterion and the KZB and / or FSV and / or MEM; comparative analysis of the calculated recipe options and their selection for experimental verification (Waller et al., 2015).
5 recipes of Turkey pates were developed, from which the most optimal recipe was selected, characterized by the lowest complex indicator reflecting the dietary properties of the finished product.

The production technology of pate included the following sequential operations: preparation of raw Turkey meat, fermentation of pork skin, preparation of meat emulsion according to the recipe by successive introduction of ingredients of the recipe, placement of the emulsion in the packaging, sterilization, quality control of finished products, storage (figure 1).

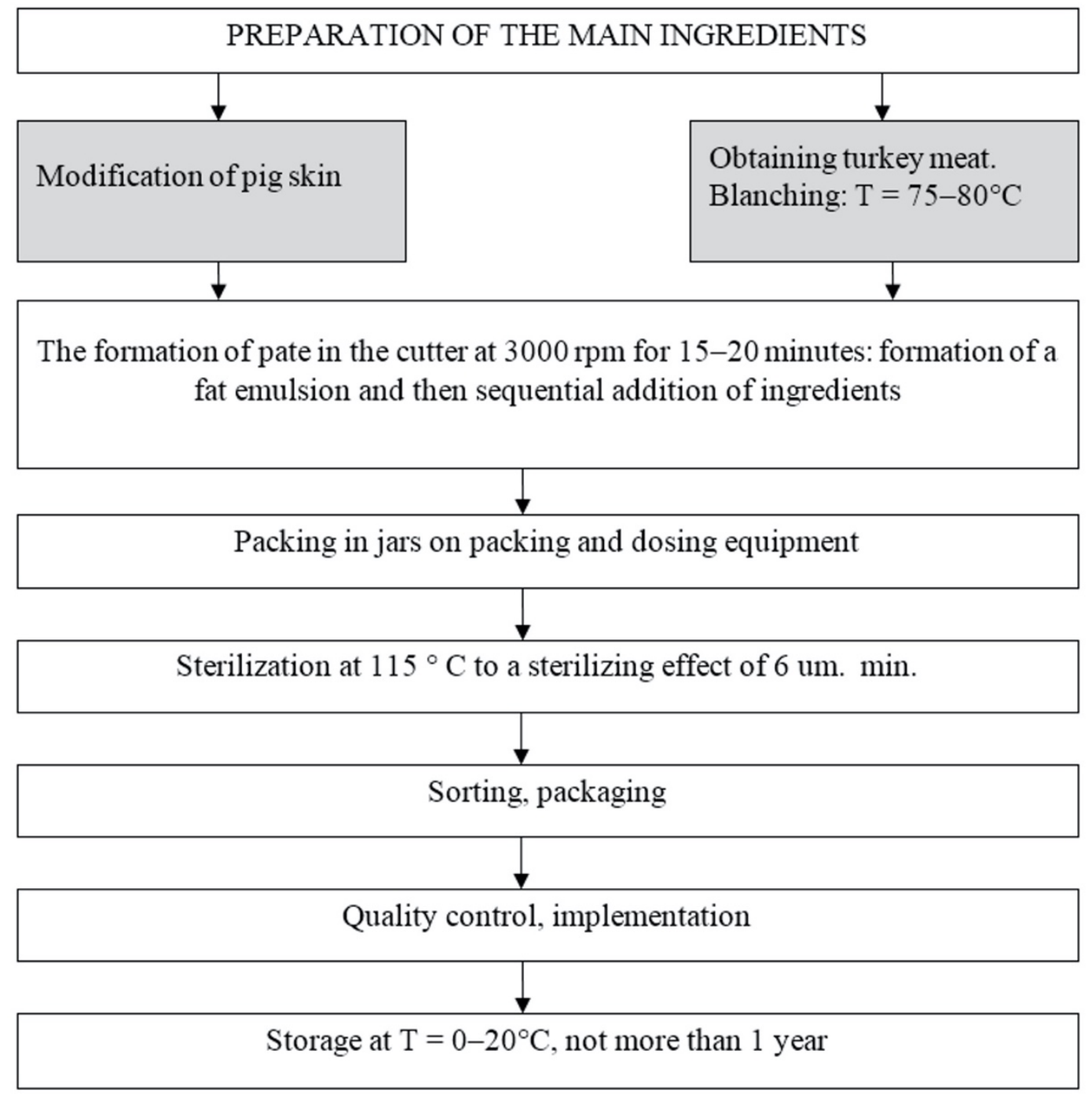

Figure 1. Flow Chart of Turkey Meat Pate Production

The content of toxic elements was determined by dry mineralization based on complete decomposition of organic substances by burning raw material samples in an electric 
furnace under controlled thermal conditions (Ibatullin et al., 2014; Verkhovna Rada of Ukraine, 1997).

The quantitative content of mercury was determined by colorimetric method based on the decomposition of the sample with a mixture of nitric and sulfuric acids, followed by colorimetric determination of copper tetraiodomercurate in comparison with the standard scale (Prilipko and Kuchus, 2014; Verkhovna Rada of Ukraine, 1997).

The quantitative content of arsenic was determined by measuring the color intensity of a solution of a complex compound of arsenic with silver nitrate in chloroform (Bouvard et al., 2015; Prylipko And Kuchus, 2014).

The content of pesticides was carried out by extraction of organochlorine pesticides with organic solvents, purification of the extract, followed by analysis of the resulting solutions on an automatic gas chromatograph with an electron capture detector (on a column of chromatographic laboratory capacity of $35 \mathrm{~cm}$ with a partition of porous glass in the lower part) to identify the composition and determine the mass fraction of pesticides.

Standard values of toxic indicators (the content of antibiotics, toxic elements, pesticides of pathogenic microflora) were determined in accordance with current regulatory documents (technical regulation of the Customs Union No. 021/2011).

The proteolytic activity of enzyme preparations was studied using the Anson method using substrate hemoglobin.

Collagenase activity was determined by the content of oxyproline in the mixture formed as a result of the action of the enzyme on native collagen.

The active acidity $(\mathrm{pH})$ was determined by a potentiometric method (Bouvard et al., 2015; Ibatullin et al., 2017).

The determination of the amount of mesophilic aerobic and optional anaerobic microorganisms was performed by counting colonies growing on solid nutrient medium after incubation at $30^{\circ} \mathrm{C}$.

Sterilization regimens were determined by a method whereby the actual lethality of Ff relative to the microflora should be equal to or exceed the required lethality of the sterilization process $F n(F f \geq F n)$. The calculation of the required mortality was carried out on CL. sporogenes microorganisms. The required lethality was calculated by the formula:

$$
\mathrm{F}_{\mathrm{H}}=\mathrm{D}(4+\lg \mathrm{CG}) \text {. }
$$

The experience was repeated five times. Statistical data processing was performed using the mathematical apparatus of the Excel program.

\section{Results and discussions}

\subsection{Results}

Regardless of the methods used, the formulation and justification of the formulations involves the following steps: formulation of requirements for the ingredients and product that meet the task; selection of ingredients that provide the desired product properties; setting acceptable levels (smallest and highest fractions) of the ingredient in the formulation; determining the optimal levels of ingredients in the recipe.

The task of calculating the optimal formulation was formulated as follows: with known lists of ingredients that are acceptable for the production of a particular product, and the characteristics of each of them (content of moisture, fat, protein, amino acids, fatty acids, trace elements, cost, etc.), as well as the required mass of the obtained of the product, it is necessary to determine in what quantities it is expedient to include the ingredients in the formulation in order to meet the established requirements for the chemical composition, quality of the finished product and the amount of use of the individual ingredients or combinations thereof, to provide the minimum (maximum) value of the optimization criterion (Ibatullin et al., 2017; Kabata-Pendias \& Szteke, 2015).

The following steps were consistently performed: data collection, systematization and analysis according to the characteristics of the selected list of ingredients and product requirements; calculation of variants of the 
optimal formulation with the selected optimization criterion and set restrictions; verification of the variant obtained for the possibility of improving the optimization criterion and KZB and / or FSW and / or MEM; comparative analysis of the calculated variants of the formulations and the choice of them for experimental verification (Waller et al., 2015).

We create a mathematical model for the calculation of raw materials for pate recipe. Denote $\mathrm{x}_{1}, \mathrm{x}_{2}, \mathrm{x}_{3}, \mathrm{x}_{4}, \mathrm{x}_{5}, \mathrm{x}_{6}, \mathrm{x}_{7}, \mathrm{x}_{8}$ as the amount of raw material of each species. $\mathrm{F}(\mathrm{x})$ is a target function that determines the content of ingredients. The mathematical interpretation of this problem will look like:

$$
\begin{gathered}
F(x)=23,5 x_{1}+24 x_{2}+36,4 x_{3}+92,3 x_{4}+4,3 x_{5}+ \\
10,3 x_{6}+38,7 x_{7}+10,8 x_{8} \rightarrow \max
\end{gathered}
$$

Based on the defined function and constraints, we create a spreadsheet in MS Excel according to functional dependency. The builtin Excel Solution Finder was used to determine the optimum composition of components.

For the most complete compliance of the product with the requirements of a healthy diet, it is necessary that the ratio of macronutrients in the product (proteins: fats: carbohydrates) is 1 : 1.3: 4; the ratio of essential amino acids lysine: tryptophan: methionine is $1: 3: 3$; the ratio of polyunsaturated: saturated: monounsaturated fatty acids is $1: 3: 6$; the ratio of trace elements: Ca: $\mathrm{Mg}$ was 1: 1.5; Ca: $\mathrm{P}$ was 1: 0.6. The formulation was optimized to match these parameters.

The result of the mathematical analysis was the development of five virtual models of canned pate recipes (Table 1). A comprehensive evaluation of the formulations obtained showed that the fifth model is optimal, with a maximum value of this indicator of 3.0 .

Table 1. Ingredients Composition and Characteristics of Virtual Recipe Models

\begin{tabular}{|l|c|c|c|c|c|}
\hline \multicolumn{1}{|c|}{$\begin{array}{c}\text { Name of ingredients } \\
\text { or indicators }\end{array}$} & I & II & III & IV & V \\
\cline { 2 - 6 } & 20.0 & 0 & 40.0 & 10.0 & 10 \\
\hline Beef liver $\left(\mathrm{X}_{6}\right)$ & 0 & 25.0 & 7.7 & 17.2 & 31.0 \\
\hline Turkey meat $\left(\mathrm{X}_{1}\right)$ & 25.0 & 0 & 15.0 & 31.9 & 16.7 \\
\hline Fat smelted $\left(\mathrm{X}_{3}\right)$ & 0 & 25.0 & 0 & 0.2 & 0 \\
\hline Sunflower oil & 15.0 & 10.0 & 0 & 8.7 & 16.7 \\
\hline Fermented pork skin $\left(\mathrm{X}_{2}\right)$ & 10.0 & 10.0 & 12.0 & 0 & 0 \\
\hline Beef brains $\left(\mathrm{X}_{8}\right)$ & 0 & 0 & 1.5 & 0 & 3.0 \\
\hline Soy protein $\left(\mathrm{X}_{4}\right)$ & 0 & 3.0 & 0 & 1.5 & 0 \\
\hline Chickpeas & 0 & 0 & 0 & 1.0 & 0 \\
\hline Wheat fiber & 5.0 & 2.0 & 4.0 & 2.5 & 0 \\
\hline Wheat flour $\left(\mathrm{X}_{7}\right)$ & 1.0 & 1.0 & 0 & 1.0 & 0.8 \\
\hline Dried onions & 21.4 & 21.4 & 17.2 & 23.4 & 20.35 \\
\hline Water added $\left(\mathrm{X}_{5}\right)$ & 1.5 & 1.5 & 1.5 & 1.5 & 0 \\
\hline Nutritional supplements & & \multicolumn{5}{c|}{ Forms } & \\
\hline
\end{tabular}


Prylipko et al./ Carpathian Journal of Food Science and Technology, 2020, 12(4), 98-112

\begin{tabular}{|c|c|c|c|c|c|}
\hline \multirow{2}{*}{$\begin{array}{l}\text { Name of ingredients } \\
\text { or indicators }\end{array}$} & \multicolumn{5}{|c|}{ Virtual recipes models } \\
\hline & $\mathbf{I}$ & II & III & IV & $\mathbf{V}$ \\
\hline Spices & 0 & 0 & 0 & 0 & 0.35 \\
\hline Salt & 1.1 & 1.1 & 1.1 & 1.1 & 1.1 \\
\hline Sugar & 0 & 0 & 0 & 0 & 0 \\
\hline Together & 100 & 100 & 100 & 100 & 100 \\
\hline \multicolumn{6}{|c|}{ Chemical composition. $\%$} \\
\hline Moisture & 53.64 & 50.64 & 61.90 & 46.86 & 64.68 \\
\hline Fat & 29.50 & 33.53 & 19.10 & 37.84 & 13.71 \\
\hline Protein & 8.15 & 8.07 & 10.48 & 7.45 & 13.01 \\
\hline Including balanced & 7.02 & 6.99 & 8.61 & 6.53 & 11.19 \\
\hline Carbohydrates & 5.96 & 2.97 & 5.76 & 4.10 & 5.51 \\
\hline Ratio M: F: C & $1: 3.64: 0.73$ & $1: 4.15: 0.37$ & $1: 1.82: 0.50$ & $1: 5.08: 0.55$ & 1:1.05:0.42 \\
\hline \multicolumn{6}{|c|}{ Amino acid composition. $g$} \\
\hline Valine & 0.404 & 0.348 & 0.692 & 0.324 & 0.664 \\
\hline Isoleucine & 0.318 & 0.333 & 0.547 & 0.283 & 0.531 \\
\hline Leucine & 0.557 & 0.584 & 0.953 & 0.499 & 0.931 \\
\hline Lysine & 0.475 & 0.522 & 0.830 & 0.444 & 0.816 \\
\hline Methionine + cysteine & 0.142 & 0.152 & 0.250 & 0.132 & 0.244 \\
\hline Threonine & 0.283 & 0.272 & 0.476 & 0.232 & 0.460 \\
\hline Tryptophan & 0.087 & 0.109 & 0.150 & 0.089 & 0.152 \\
\hline Phenylalanine + tyrosine & 0.327 & 0.321 & 0.548 & 0.277 & 0.533 \\
\hline Minimum score. (methionine) & 0.498 & 0.538 & 0.682 & 0.506 & 0.536 \\
\hline Balance factor & 0.563 & 0.592 & 0.579 & 0.592 & 0.579 \\
\hline Correlation & $1: 0.3: 0.18$ & $1: 0.29: 0.21$ & $1: 0.3: 0.18$ & $1: 0.3: 0.2$ & 1:0.30:0.19 \\
\hline \multicolumn{6}{|c|}{ Fatty acid composition. $g$} \\
\hline Saturated fatty acids $(\mathrm{H})$ & 11.25 & 5.03 & 7.07 & 14.32 & 4.62 \\
\hline $\begin{array}{l}\text { Monounsaturated fatty acids } \\
\text { (M) }\end{array}$ & 12.70 & 8.88 & 7.91 & 16.69 & 5.20 \\
\hline Polyunsaturated fat acids (P) & 3.27 & 3.75 & 2.32 & 4.41 & 1.77 \\
\hline The ratio $\mathrm{P}: \mathrm{M}: \mathrm{S}$ & $1: 3.88: 3.44$ & $1: 2.37: 1.34$ & $1: 3.41: 3.04$ & $1: 3.78: 3.25$ & $1: 2.93: 2.61$ \\
\hline
\end{tabular}


Prylipko et al./ Carpathian Journal of Food Science and Technology, 2020, 12(4), 98-112

\begin{tabular}{|l|c|c|c|c|c|}
\hline \multirow{2}{*}{$\begin{array}{c}\text { Name of ingredients } \\
\text { or indicators }\end{array}$} & I & II & III & IV & V \\
\cline { 2 - 6 } & 1.42 & 2.51 & 1.45 & 1.47 & 1.51 \\
\hline Or (P + M) / S & 4.4 & 11.5 & 12.2 & 7.7 & 12.7 \\
\hline Calcium (Ca) & 123.8 & 95.1 & 204.7 & 77.7 & 185.4 \\
\hline Phosphorus (P) & 7.9 & 12.1 & 16.3 & 9.6 & 16.8 \\
\hline Magnesium & $1: 28: 1.79$ & $1: 8.3: 1.05$ & $1: 1.6: 1.34$ & $1: 10: 1.25$ & $1: 14.6: 1.34$ \\
\hline The ratio of Ca: P: Mg & 321.0 & 338.0 & 236.0 & 386.0 & 198.0 \\
\hline \multicolumn{7}{|c|}{ Relative metrics } \\
\hline Calorie content. kcal & 0.643 & 0.625 & 0.769 & 0.583 & 1.0 \\
\hline $\begin{array}{l}\text { Protein balance } \\
\text { The ratio of unsaturated to } \\
\text { saturated fatty acids }\end{array}$ & 0.940 & 0.600 & 0.960 & 0.973 & 1.0 \\
\hline Calorie content & 0.617 & 0.586 & 0.839 & 0.513 & 1.0 \\
\hline $\begin{array}{l}\text { Comprehensive assessment of } \\
\text { formulations }\end{array}$ & 2.2 & 1.811 & 2.568 & 2.069 & 3.0 \\
\hline
\end{tabular}

Based on the results of experimental studies, we have developed a recipe for meat pate with a dietary orientation. The selection of the recipe presented in the table below was based on a comprehensive assessment of such indicators as calorie content, protein balance, and the ratio of fatty acids (saturated and unsaturated) in order to obtain a dietary product. Recipe \#5, which meets the above parameters, is shown in table 2.it is In this recipe that the complex assessment of the above parameters was the maximum (3.00), which corresponds to the requirements of the dietary product.

Table 2. The Best Recipe for Turkey Meat Pate

\begin{tabular}{|l|c|}
\hline \multicolumn{1}{|c|}{ Name } & Mass fraction of components. \% \\
\hline Turkey meat & 31.000 \\
\hline Beef liver & 10.000 \\
\hline Pork stud & 16.700 \\
\hline Soy (flour) & 3.000 \\
\hline Fermented pork skin & 16.700 \\
\hline Fresh or dried onions & 0.800 \\
\hline Salt & 1.100 \\
\hline Black pepper ground & 0.070 \\
\hline Coriander & 0.070 \\
\hline Nutmeg & 0.070 \\
\hline Carnation & 0.070 \\
\hline
\end{tabular}




\begin{tabular}{|l|c|}
\hline \multicolumn{1}{|c|}{ Name } & Mass fraction of components. \% \\
\hline Cinnamon & 0.070 \\
\hline Water & 20.350 \\
\hline Together & 100 \\
\hline
\end{tabular}

Studies on the content of antibiotics (levomycetin, tetracycline, bacitracin, grisin) have shown that Turkey meat, which is sent to the production of meat pate, does not contain antibiotic residues and can be used in production.

The results of studies to determine the content of pesticide residues in Turkey meat are shown in Table 3.

Table 3. Pesticide Content in Turkey Meat $(M \pm m, n=5)$

\begin{tabular}{|l|c|c|}
\hline \multicolumn{1}{|c|}{ List of indicators } & $\begin{array}{c}\text { Laboratory analysis } \\
\text { data }\end{array}$ & $\begin{array}{c}\text { Requirements of the regulatory } \\
\text { document }\end{array}$ \\
\hline $\begin{array}{l}\text { Hexachlorocyclohexane } \\
\text { (alpha, beta, gamma isomers) }\end{array}$ & $0.02 \pm 0.03 \mathrm{mg} / \mathrm{kg}$ & not more than $0.1 \mathrm{mg} / \mathrm{kg}$ \\
\hline DDT and its metabolites & $0.03 \pm 0.04 \mathrm{mg} / \mathrm{kg}$ & not more than $0.1 \mathrm{mg} / \mathrm{kg}$ \\
\hline
\end{tabular}

The quantitative analysis of the results of the experiments shows that the content of isomers of hexachlorocyclohexane in turkey meat is 0.02 $\mathrm{mg} / \mathrm{kg}$, which is 5 times $(\mathrm{P}<0.01)$ below the acceptable values $(0.1 \mathrm{mg} / \mathrm{kg})$. DDT and its metabolites are $0.03 \mathrm{mg} / \mathrm{kg}$, which is 3.3 times ( $\mathrm{P}<0.01)$ below normal.

Among the toxic elements, the most threatening to human health are four: lead, cadmium, arsenic and mercury, which are able to accumulate in the human body and cause diseases that manifest themselves gradually, without pronounced symptoms, and have high biological activity, oligodynamic, oligodynamic cumulative properties, the presence of specific, including remote, effects on the body. The results of the studies are shown in Table 4

Table 4. The Content of Toxic Elements in Turkey Meat $(\mathrm{M} \pm \mathrm{m}, \mathrm{n}=5)$

\begin{tabular}{|l|c|c|}
\hline \multicolumn{1}{|c|}{ List of indicators } & $\begin{array}{c}\text { Laboratory analysis } \\
\text { data }\end{array}$ & $\begin{array}{c}\text { Requirements of the regulatory } \\
\text { document }\end{array}$ \\
\hline Lead & $0.08 \pm 0.02 \mathrm{mg} / \mathrm{kg}$ & not more than $0.5 \mathrm{mg} / \mathrm{kg}$ \\
\hline Arsenic & $0.02 \pm 0.03 \mathrm{mg} / \mathrm{kg}$ & not more than $0.1 \mathrm{mg} / \mathrm{kg}$ \\
\hline Cadmium & not found & not more than $0.05 \mathrm{mg} / \mathrm{kg}$ \\
\hline Mercury & not found & not more than $0.03 \mathrm{mg} / \mathrm{kg}$ \\
\hline
\end{tabular}

Studies were conducted on the content of toxic elements in Turkey meat. The research results showed that the content of toxic elements in the studied samples met the requirements and did not exceed the maximum permissible concentrations. The results showed the following: the quantitative content of lead was
$0.08 \mathrm{mg} / \mathrm{kg}$, at $\mathrm{P}<0.05$, which is 6.2 times less than the maximum permissible concentration, the arsenic content was $0.02 \mathrm{mg} / \mathrm{kg}$ at $\mathrm{P}<0.05$, which is 5 times less than the maximum permissible concentration. The presence of cadmium and mercury in the samples was not detected. 
One of the main indicators of safety of the selected raw material is the presence of mesophilic aerobic and optional anaerobic microorganisms (MAFAnM) in it. The results of the studies are shown in Table 5.

Table 5. Results from Studies on the Detection of MAFanM Content in Turkey Meat Mesophilic Aerobic and Optional Anaerobic Microorganisms (colonies forming units per gram)

\begin{tabular}{|l|c|c|}
\hline \multicolumn{1}{|c|}{ Name of pathogens } & $\begin{array}{c}\text { Laboratory analysis } \\
\text { data }\end{array}$ & $\begin{array}{c}\text { Requirements of the regulatory } \\
\text { document }\end{array}$ \\
\hline $\begin{array}{l}\text { Mesophilic aerobic and optional } \\
\text { anaerobic microorganisms }\end{array}$ & not found & not more than $1,0 \times 10 \mathrm{KFU} / \Gamma$ \\
\hline
\end{tabular}

According to Table 6, the highest percentage $(31 \%)$ of canned pate is made from turkey meat. The specified meat raw material has undergone laboratory testing and meets the requirements of quality and safety regulations.

According to laboratory studies, the raw material found does not contain MAFanM colonies and is therefore safe for the production of meat products.

Thus, on the basis of complex analysis of turkey meat, we can conclude that the safety of meat raw materials for the production of pies of high quality and nutritional value.

Beef liver is included in the recipe in the amount of $10 \%$ of the total mass of raw materials and at its nutritional value complements the quality indicators of pate. In order to give a gentle texture to the pate, a fermented pork skin in the brine is put into the recipe.

In selecting the temperature and duration of heating of canned food come in the first place. From the fact that a properly established sterilization regime should ensure the microbiological stability of canned food. Sterilization regimes should ensure that the growth of microorganisms that are potentially harmful to human health is suppressed, as well as those that can cause damage to canned food during storage. It should be borne in mind that the heating should be as minimal as possible to ensure high organoleptic properties and nutritional value of the finished pate. Sterilization of turkey pate is carried out according to the formula:

$$
(\mathrm{A}-\mathrm{B}-\mathrm{C}) / \mathrm{T}=(25-40-25) / 115 \text {. }
$$

The developed recipe for canned meat from Turkey meat was tested at the KamianetsPodilsky meat processing plant (Ukraine). The manufactured test batch confirmed that the developed pates meet the quality and safety requirements for similar canned food.

According to the data of physicochemical studies (Table 6), the content of the main macronutrients in the studied samples was as follows: the content of the mass fraction of moisture was $66.8 \%$ at $\mathrm{P}<0.01$, fat $-20.0 \%$ at $\mathrm{P}$ $<0.01$, protein- $8.2 \%$ at $\mathrm{P}<0.01$, ash $-1.46 \%$ at $\mathrm{P}$ $<0.01$, carbohydrates- $3.5 \%$ at $\mathrm{P}<0.01$. These values correspond to the standards established in the relevant product regulations. The product turned out to be low-calorie, since its caloric content was $226.8 \mathrm{kcal}$.

Table 6. Results of Physicochemical Indices of Turkey Meat Pate

\begin{tabular}{|l|c|}
\hline \multicolumn{1}{|c|}{ Indicators } & Contents, $\%$ \\
\hline Wet & $66.8 \pm 0.5$ \\
\hline Fat & $20.0 \pm 0.25$ \\
\hline
\end{tabular}


Prylipko et al./ Carpathian Journal of Food Science and Technology, 2020, 12(4), 98-112

\begin{tabular}{|l|c|}
\hline \multicolumn{1}{|c|}{ Indicators } & Contents, $\%$ \\
\hline White & $8.2 \pm 0.09$ \\
\hline Ash & $1.46 \pm 0.02$ \\
\hline Carbohydrates & $3.5 \pm 0.03$ \\
\hline Calorie content, kcal & $226.8 \pm 1.0$ \\
\hline
\end{tabular}

According to microbiological indicators (the content of mesophilic aerobic and facultative anaerobic microorganisms and mesophilic aerobic microorganisms), canned food meets the requirements of industrial sterility.

Studies were conducted on the safety indicators of ready-made Turkey pate.

The study of the quantitative content of toxic elements in samples of turkey meat pate (Table 7) showed that the mass concentration of toxic elements did not exceed the maximum permissible values. So, the lead content was 0.02 $\mathrm{mg} / \mathrm{kg}(\mathrm{P}<0,03), 30$ times lower than the acceptable level of cadmium is $0.01 \mathrm{mg} / \mathrm{kg}(\mathrm{P}$ $<0.01)$, 30 times lower than the acceptable level of arsenic $-0,05 \mathrm{mg} / \mathrm{kg}(\mathrm{P}<0.01)$, which is 20 times below the permissible level of mercury $0.005 \mathrm{mg} / \mathrm{kg}(\mathrm{P}<0.01)$, which is 20 times below the permissible level.

Table 7. Results of a Study of the Safety of Turkey Meat Pate $(M \pm m, n=5)$

\begin{tabular}{|c|c|c|}
\hline Indexes & Content & Norm \\
\hline \multicolumn{3}{|c|}{ Concentration of toxic elements } \\
\hline Lead & $0.02 \pm 0.5$ & not more than 0.6 \\
\hline Cadmium & $0.01 \pm 0.3$ & not more than 0.3 \\
\hline Arsenic & $0.05 \pm 0.25$ & not more than 1.0 \\
\hline Mercury & $0.005 \pm 0.5$ & not more than 0.1 \\
\hline \multicolumn{3}{|c|}{ Organochlorine pesticides } \\
\hline HCG (gamma-isomer) & $0.04 \pm 0.5$ & not more than 0.1 \\
\hline DDT and its metabolites & $0.03 \pm 0.3$ & not more than 0.1 \\
\hline \multicolumn{3}{|c|}{ Antibiotics, units/g } \\
\hline Tetracycline group & not found & not more than 0.01 \\
\hline Levomycetin & not found & not more than 0.01 \\
\hline Bacitracin & not found & not more than 0.02 \\
\hline Grisin & not found & not more than 0.5 \\
\hline \multicolumn{3}{|c|}{ Radionuclides, $\mathrm{Bq} / \mathrm{kg}$} \\
\hline Cs-137 & not found & not more than 180 \\
\hline Sr-90 & not found & not more than 80 \\
\hline
\end{tabular}

The content of organochlorine pesticides did not exceed the norm and corresponded to the quantitative value: for the gamma-isomer of $\mathrm{HCG}-0.04 \mathrm{mg} / \mathrm{kg}$, which is 2.5 times less than the maximum permissible value of $0.1 \mathrm{mg} / \mathrm{kg}$, for DDT and its metabolites $-0.03 \mathrm{mg} / \mathrm{kg}$, which is 3.3 times less than the maximum permissible value of $0.1 \mathrm{mg} / \mathrm{kg}$.
The residues of antibiotics and radionuclides were not detected at all.

\subsection{Discussions}

Our analysis of the literature shows that it is currently particularly effective to produce new types of meat products that include multicomponent emulsions based on new types of 
meat raw materials (Alahakoon et al., 2015; Bouvard et al., 2015). From the analysis of literature sources, it follows that the development of recipes for pates from nontraditional raw materials and raw ingredients that can provide high quality canned pates is of practical interest. And such raw materials as Turkey meat can be attributed to dietary meat (Anufriev, Kolmykov, Emelyanov, \& Zinina, 2016; Krishtafovich, Krishtafovich, \& Sharafutdinova, 2014; Starikova, 2015).

In 2017, the volume of the world market for Turkey meat was 6305 thousand tons. The following year, there was a marked increase in the market against the background of increased consumption in the United States, Brazil, and Russia. According to the research by IndexBox Russia, the market has grown by $+3.1 \%$ per year on average in wholesale prices over the past ten years and amounted to $\$ 13.2$ billion. USA. The US remains the key Turkey-producing country in the world. At the beginning of the last decade, Canada became the second country in terms of Turkey meat production in America - 153 thousand tons per year (Alahakoon et al., 2015; Bouvard et al., 2015).

The calculations described above, performed using computer modeling methods, allowed us to develop recipes for preparing Turkey pates that meet the average daily needs. Our assessment of the nutritional adequacy of virtual pate models for all 5 recipes (the Recipes for all five pates are presented in Table 1) showed that the fifth model is optimal (table 2), with a maximum value of 3.0. This recipe, unlike other developed models, contains the largest amount of Turkey meat, while the fat content is minimized, the liver content is significantly reduced, and wheat flour is present. It was possible to balance the amino acid composition by introducing chickpea flour into the recipe. Chickpea proteins can replace animal proteins by their biological value, since they are a source of essential amino acids, in particular methionine, lysine and tryptophan. Due to the high protein content in chickpea flour, there are many purine bases. A number of authors suggest correcting the nutritional value of meat pates by introducing them with high-intensity nutritional components. For example, Baranenko D. A. and co-authors suggest using an enzyme preparation of proteolytic action, including chymotrypsin and pepsin in a ratio of 1: 1 , to increase the nutritional value of connective tissue. At the same time, optimization of technological parameters of protein proteolysis allows to obtain a maximum value of 3.1 (Baranenko, 2013). Stepanova E. A. it is proposed to use paprika with herbs, garlic, cranberries, buckwheat flour in the production of pate, which allows you to get a product with a piquant taste (Stepanova, 2017). Esmat, Asuggest use pumpkin in the recipe of meat and vegetable pate based on horse meat and chicken liver. The proposed composition provides a product with dietary, hypoallergenic and antioxidant properties (Hassan, Hussein, \& Hussein, 2013). $\mathrm{Rui} \mathrm{Xu}$ developed pates with a protein product from melon seeds of reduced caloric content, enriched with an additional amount of trace elements and vitamins (Xu, 2012).

The use of strict input control allowed us to achieve high food safety of the final product . Thus, the studied safety indicators are both in raw Turkey meat (table 3-5) and in finished products (table 3-5). 7) meet the required parameters.

Turkey meat does not contain pesticides or antibiotics, which are regulated by law. The content of heavy metals is significantly lower than the normalized one. Due to the short term of fattening, Turkey meat is an environmentally safe raw material.

Our results are consistent with data from a number of domestic and foreign researchers who show that Turkey meat does not contain pesticides or antibiotics, since it is not used in poultry farming (Chernukha, Smetanina, Kuznetsova, \& Lisitsyn, 2005; De Mey et al., 2014; Ibatullin et al., 2014, 2017; JiménezColmenero et al., 2010, p.). This result is very important because it indicates that Turkey meat does not accumulate toxic compounds in high concentrations. The content of heavy metals is significantly lower than the normalized one. Our results are consistent with many studies on the bioconversion of toxic compounds from the environment into the muscle tissue of Turkey 
meat (Baranenko, 2013; Chernukha et al., 2005; Levy et al., 2016; Prylipko \& Kucius, 2014). Based on this data, we can recommend the use of Turkey meat for the production of pates in any region.

Based on the results of market research conducted in various countries, we believe that poultry meat and its processed products are socially important goods, and the volume of their production is a criterion for ensuring the country's food security. Pates have recently gained popularity among consumers as a readyto-eat product with a high calorie content, as an alternative to meat and sausage products. The results of the evaluation of the nutritional value of Turkey meat pate showed a high content of protein $(21.2 \%)$, carbohydrates $(3.5 \%)$, trace elements $(1.46 \%)$, and a balanced energy value of $226.8 \mathrm{kcal}$, which is confirmed by many studies (Anufriev et al., 2016; Bazhenova, Khamaganova, Pavlova, \& Badmayeva, 2005; Krishtafovich et al., 2014). Therefore, poultry pates have a high biological value, and the business idea of producing high-quality meat pates is quite popular and financially attractive (Alahakoon et al., 2015; Chicken \& Turkey Meat Production in Canada-Market Research Report, 2019; De Mey et al., 2014; Decker \& Park, 2010).

Turkey meat is in stable demand in North America, Europe, and Latin America, but per capita consumption varies from country to country. Consumption of Turkey meat, like other types of meat, depends significantly on the population and disposable income, so countries with a high standard of living traditionally have a high consumption of Turkey per capita. In addition, Turkey meat is characterized by a seasonality factor - demand in the United States and Europe increases annually during the preholiday period, for example, in the run-up to Christmas (Chicken \& Turkey Meat Production in Canada-Market Research Report, 2019; Kabata-Pendias \& Szteke, 2015; Menon \& Rumer, 2015).

The method of sterilization is widely used to increase the shelf life of meat products. A number of authors, including Kabata-Pendias \& Szteke (2015), Ibatullin I. I. and co-authors
(Ibatullin et al., 2014) believe that sterilization regimes in the production of pates smooth out differences between different types of prescription components, leveling the quality of canned food and eliminating the influence of raw material quality. However, we have shown that the sterilization of canned food using classical technology is the basis for ensuring not only high sanitary and hygienic indicators of their quality, but also preserving the individual composition and characteristics of the product. The proposed regime of thermal preservation guarantees the death of pathogenic and toxigenic microorganisms and microflora that cause spoilage of products.

The sterilization modes proposed in our work-at a temperature of $115^{\circ} \mathrm{C}$-allowed us to obtain the necessary sterilizing effect. Thus, microbiological studies of Turkey meat have shown that Mafanm (CFU/g) is 1x102, which is three orders of magnitude lower than the requirements for raw materials. No pathogenic microorganisms were detected.

Due to the small size of the carcasses, their manual deboning is extremely time-consuming. Nevertheless, in the works of Decker E. A. and co-authors (Decker \& Park, 2010), it is noted that the use of mechanical boning in their processing is of great interest. After sterilization, the quality indicators of the finished pate showed its high nutritional value. Values of indicators of nutritional and biological value, amino acid, fatty acid and mineral balance (data are presented in Table 1 and Table 6) allowed us to classify Turkey meat pates as functional products. According to our research, Turkey pate contains $25-27 \%$ dry matter, $21-22 \%$ protein and $2.5-4.0 \%$ fat. We agree with the authors who claim that the chemical composition of Turkey meat pate can be attributed to dietary products (Chicken \& Turkey Meat Production in Canada-Market Research Report, 2019; Xu, 2012). Turkey meat is tastier and healthier than chicken, pork, and beef, and contains a large amount of vitamins and trace elements. Turkey meat is well absorbed by the body, its digestibility is $90 \%$.

The combined analysis of all the data presented strongly suggests that Turkey meat 
obtained as a result of mechanical deboning can be used in the production of pates.

Based on the research of functional, technological and microbiological parameters of meat, vegetable raw materials and the finished product, rational modes of production and storage of Turkey meat pates with guaranteed safety and high nutritional and biological value have been established.

The technological scheme for the production of Turkey pates for functional nutrition presented in figure 1 includes all the necessary operations for the preparation of raw materials and components of the recipe. The formation of the meat emulsion at a rotation speed of 3000 rpm should continue for 15-20 minutes, then the ingredients are added sequentially to the resulting fat emulsion. For the described parameters of the production process, it is recommended to store the finished product at $\mathrm{T}$ $=0^{\circ} \mathrm{C}-20^{\circ} \mathrm{C}$, no more than 1 year.

Although Turkey is a much less common type of meat than chicken, there is expected to be a gradual increase in consumer interest in Turkey against the background of a growing trend in the popularity of "healthy" food in developed countries and increased attention to low-fat foods.

\section{Conclusions}

Based on the research of the biochemical composition and calculation of nutritional value, the choice of ingredients for cooking canned Turkey pate of a new generation was justified. As a result of mathematical analysis, five virtual models of canned pate recipes were developed. A comprehensive assessment of the obtained recipes showed that the recipe, in which the content of Turkey meat was $31 \%$, used beef liver to give a tender consistency, which in its nutritional value complements the quality indicators of pate, as well as fermented pork, is optimal.

Qualitative characteristics of mechanical deboning of Turkey meat were studied. As a result, high protein content, low fat content and high iron content were found, which allows us to classify this raw material as a dietary material with a functional focus on the body of a vitamin and mineral complex.

To further optimize the recipe, it is necessary to continue research on changes in the qualitative and quantitative composition of the main food nutrients during the heat treatment process. This will allow you to get a dietary, but at the same time very nutritious product from environmentally safe and useful meat raw materials.

\section{References}

Alahakoon, A. U., Jayasena, D. D., Ramachandra, S., \& Jo, C. (2015). Alternatives to nitrite in processed meat: Up to date. Trends in Food Science \& Technology, 45(1), 37-49. https://doi.org/10.1016/j.tifs.2015.05.008

Anufriev, I. P., Kolmykov, M. A., Emelyanov, D. V., \& Zinina, O. V. (2016). Medicobiological and economic justification of the production of pate from duck offal. Young Scientist, 8, 179-182. (in Russian)

Baranenko, D. A. (2013). Tekhnologiya myasnykh

produktovizbiomodifitsirovannogosyr'ya

[Technology of meat products from biomodified raw materials]. Scientific Journal of Saint Petersburg National Research University of Information Technologies, Mechanics and Optics (NRU ITMO). Series 'Processes and Devices of Food Production', 2(16), 200-206. (in Russian)

Bazhenova, B. A., Khamaganova, I. V., Pavlova, S. N., \& Badmayeva, T. M. (Eds.). (2005). Tsenka kachestva myasnykh i myasorastitel'nykh banochnykh konservov: Metodicheskiye ukazaniya $\mathrm{k}$ laboratornoy rabote [Assessment of the quality of meat and meat-growing canned food: Guidelines]. Ulan-Ude: Izdatel'stvo VSGTU. (in Russian)

Bouvard, V., Loomis, D., Guyton, K. Z., Grosse, Y., Ghissassi, F. E., Benbrahim-Tallaa, L.,Straif, K. (2015). Carcinogenicity of consumption of red and processed meat. The Lancet Oncology, 16(16), 1599-1600. 
https://doi.org/10.1016/S1470-

2045(15)00444-1

Chernukha, I. M., Smetanina, L. B., Kuznetsova, T. G., \& Lisitsyn, B. A. (2005). Modification of low-grade raw materials by animal enzymes in the production of meat Products. Tehnologija Mesa [Meat Technologies], 46(5-6), 271-278.

Chicken \& Turkey Meat Production in Canada-Market Research Report [Report]. (2019). Retrieved from https:/www.ibisworld.com/canada/marketresearch-reports/chicken-turkey-meatproduction-industry/

De Mey, E., De Klerck, K., De Maere, H., Dewulf, L., Derdelinckx, G., Peeters, M.-C., ... Paelinck, H. (2014). The occurrence of $\mathrm{N}$-nitrosamines, residual nitrite and biogenic amines in commercial dry fermented sausages and evaluation of their occasional relation. Meat Science, 96(2), 821-828. https://doi.org/10.1016/j.meatsci.2013.09.0 10

Decker, E. A., \& Park, Y. (2010). Healthier meat products as functional foods. Meat Science, 86(1), 49-55. https://doi.org/10.1016/j.meatsci.2010.04.0 21

Hassan, E., Hussein, A., \& Hussein, A. (2013). Chemical, Rheological and Sensory Evaluation of Pate Stuffed with Broccoli (Brassica oleraceae L.). Polish Journal of Food and Nutrition Sciences, 63(4), 245252. https://doi.org/10.2478/v10222-0120086-0

Ibatullin, I. I., MelK№nyk, Yu. F., Otchenashko, V. V., Chigrin, A. I., Kondratyuk, V. M., \& et al. (2014). Praktykum $\mathrm{z}$ hoduvannya sil's'kohospodars'kykh tvaryn: Navchal'nyy posibnyk [Farm Animals Workshop: Textbook. Kyiv. (in Ukraian)

Ibatullin, I. I., Zhukorsky, O. M., Bashchenko, M. I., Kovtun, S. I., Kopilov, K. V., \& et al. (2017). Metodolohiya ta orhanizatsiya naukovykh doslidzhenK№ u tvarynnytstvi: Posibnyk [Methodology and organization of scientific research in animal husbandry: Manual. Kyiv: Agrarian Science. (in Ukraian)
Jiménez-Colmenero, F., Sánchez-Muniz, F. J., \& Olmedilla-Alonso, B. (2010). Design and development of meat-based functional foods with walnut: Technological, nutritional and health impact. Food Chemistry, 123(4), 959-967.

https://doi.org/10.1016/j.foodchem.2010.05 .104

Kabata-Pendias, A., \& Szteke, B. (2015). Trace Elements in Abiotic and Biotic Environments (1st ed.). Boca Raton, FL: CRC Press. https://doi.org/10.1201/b18198

Krishtafovich, V. I., Krishtafovich, D. V., \& Sharafutdinova, K. R. (2014). Pishchevaya tsennost' natural'nykh polufabrikatov iz myasa muskusnykh utok [Nutritional value of semi-finished natural musk duck meat]. Actual Biotechnology, 2(9), 43-48. (in Russian)

Levy, M., Thaiss, C. A., \& Elinav, E. (2016). Metabolites: Messengers between the microbiota and the immune system. Genes \& Development, 30(14), 1589-1597. https://doi.org/10.1101/gad.284091.116

Menon, R., \& Rumer, E. B. (2015). Conflict in Ukraine: The unwinding of the post-Cold War order. Cambridge, MA: The MIT Press.

Prylipko, T. M., \& Kucius, V. M. (2014). Obgruntuvannya rezhymnykh parametriv protsesu sterylizatsiyi m'yasnykh konserviv [Substantiation of regime parameters of the process of sterilization of canned meat]. In B. V. Egorov (Ed.), Proceedings of the Odessa National Academy of Food Technologies: Technical Sciences: Vol. Issue 46, Vol. 2 (pp. 177-182). Odessa: Odessa National Academy of Food Technologies. (in Ukraian)

Starikova, N. A. (2015). Modern trends in food industry technology. Science of SUSU: Materials of the 67th Scientific Conference. Sections of Technical Sciences, 546-551. Chelyabinsk: Publishing Center of SUSU. (in Russian)

Stepanova, E. A. (2017). Production of meat pates with paprika and herbs, garlic, cranberries/ Modern science-intensive technologies. International Scientific 
Conference Modern Science Intensive Technologies, 3, 46. (in Russian)

Technical regulation of the Customs Union no 021/2011.

Verkhovna Rada of Ukraine. (1997). Pro osnovni pryntsypy ta vymohy do bezpechnosti ta yakosti kharchovykh produktiv [On quality and safety of food products and food raw materials] Pub. L. No. 771/97-VR of 23.12.1997 (as amended by Law No. 1602-VII of 22.07.2014, Information of the Verkhovna Rada of Ukraine, 2014, No. 41-42, Article 2024, as amended by Laws No. 67 -VIII of 28.12.2014, Information of the Verkhovna Rada of Ukraine, 2015, No. 4, Article 19, as amended by Law No. 867-VIII of $08 / 12 / 2015$, Information of the Verkhovna Rada of Ukraine, 2016, No. 4, Article 40). Retrieved from https://zakon.rada.gov.ua/laws/main/inex (in Ukraian)

Waller, U., Buhmann, A. K., Ernst, A., Hanke, V., Kulakowski, A., Wecker, B., ... Papenbrock, J. (2015). Integrated multitrophic aquaculture in a zero-exchange recirculation aquaculture system for marine fish and hydroponic halophyte production. Aquaculture International, 23(6), 14731489. https://doi.org/10.1007/s10499-0159898-3

$\mathrm{Xu}, \mathrm{R}$. (2012). Oat fibre: Overview on their main biological properties. European Food Research and Technology, 234(4), 563-569. https://doi.org/10.1007/s00217-012-1666-2 